\title{
DISTANCE LEARNING ON FORMATION OF TECHNICAL COMPETENCIES OF UNIVERSITY STUDENTS (ON THE EXAMPLE OF NATURAL SCIENCES)
}

Gulnara K. Nauryzbayeva ${ }^{1}$, PhD student; Gita Revalde ${ }^{2}$, Dr. Prof.;

Gulmira L. Gabdullina ${ }^{3}$, Candidate of Phys.-Mat. Sciences, Senior Teacher;

Guldana T. Aldzhambekova4, Candidate of Technical Sciences, Associate Professor;

Kamila Adilzhan ${ }^{5}$, PhD student

1,3,5Al-Farabi Kazakh National University, ${ }^{2}$ Riga Technical University, ${ }^{3}$ Almaty University of

Power Engineering and Telecommunications after named G. Daukeev, ${ }^{4}$ International University of Information Technology

\begin{abstract}
This paper presents our model of the organization and content of distance learning in physics for the formation of technical competencies of university students. An example of the organization of lectures on the topic "Electromagnetic induction" for students of the specialty "Power Engineering" is given. The organization of other forms of education is also given. The aim of the work is to develop technical competencies in students. A professionally oriented approach was used in teaching physics. The content of distance learning, presented through the electronic educational and methodological complex of the discipline, has been determined. The activities of teaching and learning of students are regulated, methods, forms and means of online distance learning are selected, at present, as methods of organizing activities, the result of educational activities reflects the quality of training in accordance with the successful teaching activities of students, as well as its diagnostics and control. The possibility of improving the quality of training in physics, increasing the levels of formation of technical competencies of future bachelors in the field of energy is shown on the example of distance learning in physics online, based on the use of professionally oriented training. The results of survey of the first year distance learning students showed quite high satisfaction, also for the students living in the rural regions in Kazakhstan.
\end{abstract}

Key words: physics, technical competencies, synchronous distance learning, asynchronous distance learning, student. JEL code: I25

\section{Introduction}

Changes in the requirements in the world for professional training have led to the emergence of a number of tasks in teaching students of a technical university at the level of disciplines of the natural science cycle, which are due to the following factors:

- changing the requirements for the quality of training of technical specialists;

- changing goals, curricula and programs;

- the need to introduce new teaching technologies aimed at enhancing the role of students' independent activity (Aldous H., 2000; Armstrong M., Baron A., 2004). The training of a specialist for the engineering and technical sphere of labour, the formation of his personal qualities can be carried out by giving the educational process and the content of training in a higher educational institution a professional orientation (Boyatzis L., Richard E., 1982). Currently, the attention of many teachers is attracted by the organization of optimal conditions, the formation of the technical competencies of the future engineer in the learning process, the creation of conditions for personal growth and the development of their cognitive interests (Cakir M., 2008; Byham W. C., 2016).

Today, according to the State Program "Digital Kazakhstan" for 2017-2021, it is planned to improve the life quality and the competitiveness of the republic's economy through the accelerated development of digital ecosystem, primarily, by creating conditions for the development of technological entrepreneurship with stable links between business, science and the Government, as well as the introduction of innovations

1 Al-Farabi Kazakh National University, Kazakhstan, 050040, Almaty, al-Farabi Avenue, 71; e-mail: N_G.K@mail.ru

2 Institute of Technical Physics, Department of Materials Science and Applied Chemistry, Riga Technical University, Riga, Latvia

3 Almaty University of Power Engineering and Telecommunications after named G. Daukeev, Kazakhstan, 050013, Almaty, st. Baytursynuly, 126

4 International University of Information Technology, Kazakhstan, 050040, Almaty, st. Manas, 34 A 
into the education system (Digital Kazakhstan, 2010). Digitalization, especially in higher education, is of paramount importance for the development of rural regions in Kazakhstan, because $67 \%$ of the population is living in rural areas.

In the framework of implementation of this program, the modern organization of universities educational activities in the country suppose the teaching in condition of need for digitalization of education using information technologies, such as computer learning technologies, interactive multimedia, teaching based on web technologies, online training, distance learning, which have important roles in training specialists in engineering education. Providing high-quality distance education is very crucial for the accessibility of education. The introduction of distance learning has also been accelerated by the COVID-19 pandemics.

Thereby, educational institutions are digitalizing the educational process, actively developing online, massive open online courses and distance learning, using the latest achievements of information technology. In the light of recent events, in the fierce need to move to online learning, the organization of educational process must correspond to the educational and methodological complex of a discipline, and each developed course is divided to certain modules dedicated to a specific topic. The developed thematic module should be based on competencies and form specific learning outcomes. Illustrated lectures, tests and tasks for self-control, practical exercises in the form of virtual, remote laboratories, final control form the basis of the module. With the unification of the teaching system for engineers by the introduction of a qualification framework, the educational teaching standard for engineering should provide a link with professional standards as a key document for the development of various educational programs in the field of engineering technologies (Martin L., 2013). In this regard, distance education received an additional load on the teaching system of future bachelors in the field of engineering work in the form of requirements for the quality of future professional activities, its practical composition, and readiness to apply knowledge in practice. This position determines the great demand for the definition of new models of education for training students already in junior course, focused on mastering skills in disciplines related to future professional activities, the growth and development of their personal qualities: professional orientation and competency, cognitive activity and independence, etc.

The aim of this paper is to present our model for teaching technical competences in Physics education at the university level in the conditions of distance learning. As said before, the introduction of distance learning was accelerated worldwide due to the COVID-19 pandemics, however the concerns about the quality remain.

The research hypothesis is to show that the quality of teaching physics in the case of distance learning is maintained at high quality, using the elaborated model of developing technical competences. In the process of forming the technical competencies of students, professionally oriented teaching of physics was used. To prove the hypothesis, we use a case study of the formation of technical competencies of future bachelors in the field of energy. Based on the results of the study, the effectiveness of professionally directed training has been proven. Detailed analysis is given on the examples of organisation of the educational process in distance learning on the selected topic for students of the specialty "Power Engineering".

The novelty of the work is the filling of the physics course with technical content. Based on the results obtained, digitalization of education using the example of online distance learning in physics based on the use of professionally oriented training, showed the possibility of improving the quality of training in the discipline studied, increasing the levels of formation of technical competencies of future bachelors in the field of energy (agriculture). 
As far as we know, this is a first attempt to elaborate a method of the development of technical competences in Physics education in the field of electrical engineering in distance learning conditions.

\section{Research results and discussion}

From a psychological point of view, readiness for professional activity is characterized by the presence of a specialist's knowledge, skills and abilities that allow him to carry out his activities at the level of modern requirements of science and technology (Borisova L. A., 2006). In this connection, a special place should be given to the formation of technical competencies of a future bachelor, i.e. a complex of knowledge, skills and abilities and personal qualities that determine the effectiveness of engineering work. It should be noted that students at technical universities begin to acquire professional practical skills in the field of their chosen specialty in senior courses, in manufacturing or in research laboratories after studying a physics course.

The teaching continuity in this case, in our opinion, can be achieved by switching to teaching physics while simultaneously using the principles of personality-activity and professionally-directed learning in the context of a model of technical specialist.

The main purpose of such specialist is the determination of the object of practical professional activity of a future bachelor (Tashkeyeva G., 2014; 2020). This allows to align the educational activities of students with their future professional ones by defining professional tasks from the model of specialist working in the electric power industry.

In accordance with the goals and objectives, the content of distance learning is determined, presented through the electronic educational and methodological complex of the discipline. The activities of teaching and learning of students are regulated, methods, forms and means of online distance learning are selected, at present, as ways of organizing activities, the result of educational activities reflects the teaching quality in accordance with the successful teaching activities of students, as well as its diagnostics and control (Figure 1).

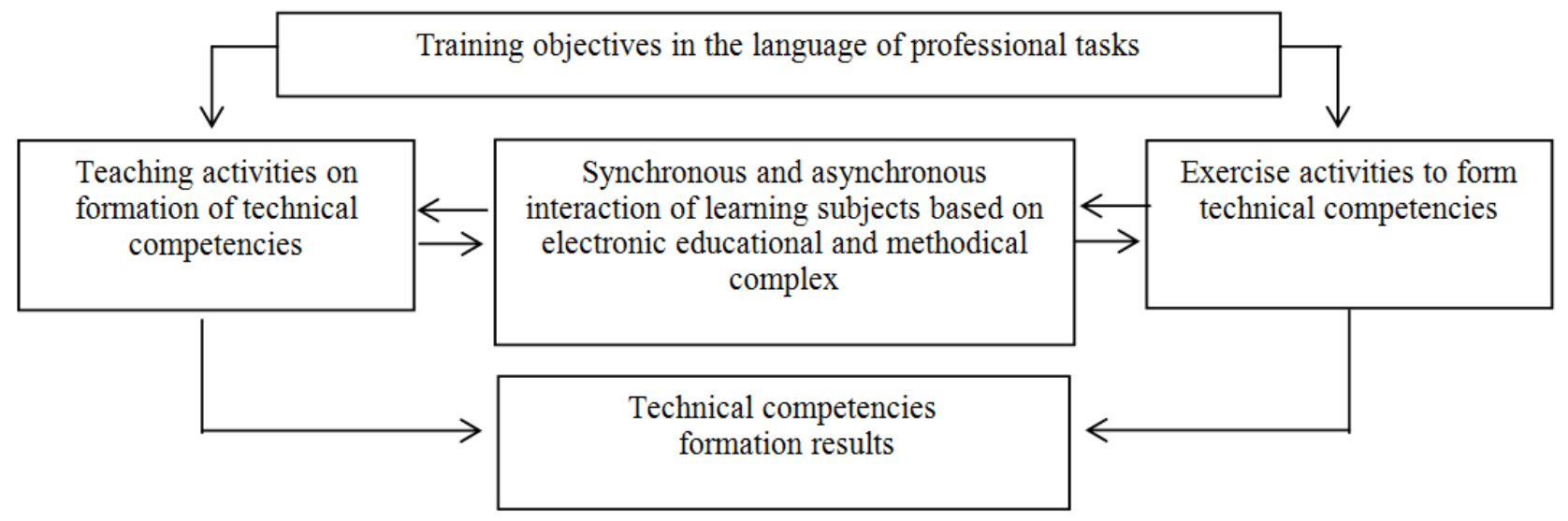

\section{Source: author's model}

Fig. 1. Schematic representation of the development of the content of distance learning on physics for formation of technical competencies of students

In this case, the formation of technical competencies can be effectively realized in the context of teaching students, providing that the content and methods of distance learning in physics are focused on a model of professional activity, founded on a competency-based approach to professional training (Zvezdova A. B., 2012; Arabadzhi V. A., 2010).

Technical competencies consist of three criteria components (activity and independence; awareness of the role, function and importance of a specialist; relation to himself as a subject of future professional activity) and three components of indicators (value-motivational, content-based and technological). In 
accordance with the criteria and indicators, there are four levels in the structure of students' technical competences: high, sufficient, medium, low levels of technical competences formation (Ageeva N., 2004).

In a digital format, online teaching provides, as known, there are synchronous (electronic interaction between a teacher and a student at a certain time) and asynchronous (students work at any time with information uploaded to the system) types of teaching. To conduct a professionally directed online lesson with maximum benefit for both sides, teachers need to combine the synchronous lesson with the asynchronous one. For these purposes a student should read the content of a lecture in advance, which was uploaded by a teacher as a video lecture, presentations or other materials on the discipline under study to the system of a chosen platform (Microsoft Teams, Platonus, Moodle, Univer, Google Classroom etc.). Thus, the authors of the article prepared presentations and video lectures for the course "Physics".

Let us give an example on the topic of lecture "Electromagnetic induction" for students of the specialty "Power Engineering". The goals of the lecture are to understand the physical meaning of the phenomenon of electromagnetic induction and its consequences. During a video lecture, a teacher talks about the discovery of Faraday, explains Lenz's rule and the physical nature of electromagnetic induction, as well as illustrates the phenomenon of self-induction and mutual induction, eddy currents, etc. For preview purposes, students are shown a clear and understandable video lecture. Here you need to pay attention to the design of a slide, the content of each slide should be accompanied by its application in technology and everyday life, for example, where are used the devices, installations prepared based on electromagnetic phenomena (household electrical appliances, microwave, the principle of operation of the generator, etc.). At the end of the lecture, students are offered questions for self-development and study the lecture material. During a synchronous teaching, teacher discusses the lecture materials with students, asks questions, explains some problems, and questions asked by students. Moreover, the construction of a physics course using the goals and objectives of teaching identified in this way, obtained due to knowledge of professional tasks of the specialty, orients the content and technology of teaching for future professional activities based on the idea of the unity of fundamental knowledge and applied knowledge, taking into account the role of physics in the development of Power Engineering systems and their functioning in the above example. For this, the content of lectures and practical classes, students' independent work, laboratory work with technical content are used. An example is not only the selection of the lecture material content in accordance with the set learning objectives, but also the widespread use of computer modelling methods, which make it possible to show the application of certain laws and phenomena of physics in obtaining modern Power Engineering systems. Moreover, some of the presentations are prepared by students themselves on a given topic for a synchronous lesson. The main point of this form of work is to teach students to find a solution to a problem on their own, develop the necessary competencies and teach them how to work with information. Solving problems and performing laboratory work is related both to the sections of the course and has technical content focused on the use of the laws of physics in various Power Engineering systems in general (obtaining information, converting it into electrical signals and signs, distribution, conservation, and possible energy losses).

For the performance of computational and graphic tasks for the section "Electricity and Magnetism" students are offered part of the tasks with technical content. An example is the following level A task: "The mass of a tram moving uniformly at a speed of $35 \mathrm{~km} / \mathrm{h}$ is 18 tonnes. The movement resistance coefficient is 0.01 . Find the current $\mathrm{I}$ in the motor winding if the voltage is $545 \mathrm{~V}$ and the efficiency is $85 \% "$. In solving problems with technical content, students have the opportunity not only to see the application of the laws of physics from different sections, but also their connection with practice. 
Further, when drawing up test tasks, midterm control, different control works, methodological instructions for performing computational and graphic works, physical tasks should be included in the tasks not only with technical content, but also with their possible modelling using information and communication technologies. If it is difficult to solve such problems, a student can look at already existing solved problems with technical content, recommended by teacher (hyperlinks), the possibilities of their modelling. Physical problems with technical content are real practice-oriented problems of physics; they contain information about the principles of action of mechanisms and machines, transmission and conversion of energy, etc. If throughout the entire training period, physical tasks of technical content are applied, then the quality of training of future engineers can increase significantly. Solving such problems, students acquire new competencies not only in physics, in the studied physical concepts, phenomena and their laws, receive information about new achievements, problems of science and technology, features of the professional activity of engineers, but as a result they consciously acquire technical competencies (Mazhitova L., 2010).

Thus, a teacher, with a certain expenditure of his time and effort, can be confident in the assimilation of this material by students in the context of their future professional training at the university in the senior years. Within the framework of the physics course, there are enough opportunities to create this kind of educational material, material, especially those materials that affect the technical application of the phenomenon in question.

Laboratory studies play an important role in teaching physics. One of the important trends in the application of information technology in online distance learning is the creation of virtual works, which are an integral part of any technical discipline. Based on new information and communication technologies using Microsoft Teams applications, online laboratory work can be organized at a new level. In this regard, we have prepared the author's virtual laboratory work on the physics section "Mechanics" for students on the topic: "Study of gyroscopic effect". The work presents the title, goals and objectives, a brief theory of studying the gyroscopic effect and its use in practice, the experimental method and the setup diagram, the procedure for performing the measurements, tables for the experimental results, tests with five answers for each test, which can be used to testing students' knowledge on a given topic. In the work there is also the possibility of obtaining the results after the teacher has entered the password, which is very convenient for distance learning.

At the same time, during the period of distance learning, students can and should be involved in research work, which contributes to the formation of competencies related to the development of computer models of physical phenomena, working diagrams and installations, to participate in international online conferences and exhibitions with independently simulated phenomena and laws of physics, but associated with their application in practice in energy efficiency systems. An example is the research work of students of the group EE-18-2 Marat Yafarov on the topic "Solar collector" and the group PE-19-1 Nurbek K. on the topic "Sources of alternative energy. Getting electricity through a strong stream of water" (Mazhitova L., 2010).

A scientific approach to solving online learning problems requires a thorough study of the initial state of the system and identifying its problems. In this regard, we carried out a survey of first-year distance learning students of the study programme Electrical Engineering, which study physics at the University of Power Engineering and Telecommunication, Almaty, Kazakhstan. Students were asked to fill out a questionnaire developed by us, which contains several questions and points that allow students to state their difficulties in studying physics in online format and express their wishes:

1) How did you adapt to the new conditions of distance learning? 

2) Is there a timely notification of changes in the distance learning process?
3) Is it convenient for you to study remotely?
4) What is your level of motivation for learning in the distance form?
5) Are you satisfied with the distance learning process?
6) How do you assess the work of the teaching staff in the framework of distance learning?
7) What difficulties did you face in the process of distance learning?
8) What technical challenges did you face with distance learning?
9) What did you like about distance learning?
10) What did you dislike about distance learning? What are your wishes for improving distance learning?
11) In total, 103 questionnaires were distributed, the number of respondents participating in the survey was 76 , making $74 \%$ form the total.

As follows from the results of the questionnaires, $33 \%$ of the students lived during their studies in villages, $20 \%$ - in districts, $47 \%$ - in cities of Kazakhstan.

On 1-2 questions, some of the students answered that the transition to distance learning caused certain difficulties, for many students this is associated with an increase in the level of anxiety, and timely notification of changes in the distance learning process is received depending on access to the Internet, and to the third question, students from remote rural areas answered that it is not convenient to study remotely due to the poor Internet network.

By answering questions 4-6, the level of their training in physics was assessed. On the issue of the difficulties of studying physics online, 29 students wrote that they did not experience any difficulties, 47 minor difficulties - these are students, mainly from South Kazakhstan and West Kazakhstan regions (Figure 2, 3).

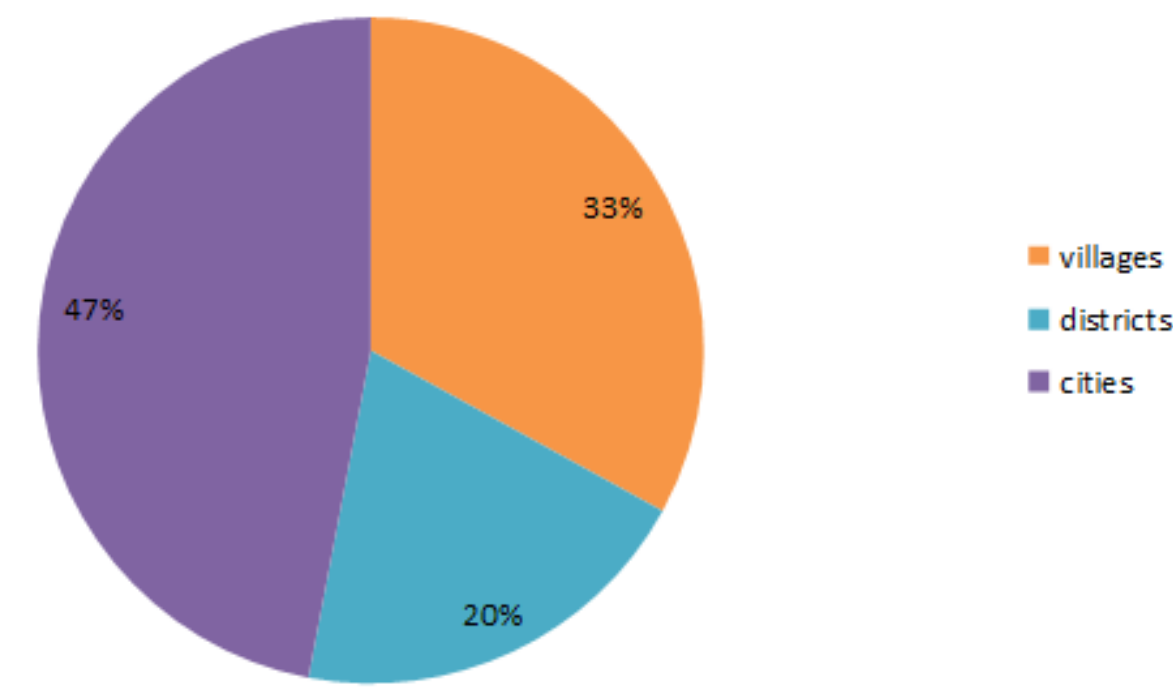

\section{Source: author's survey}

Fig. 2. Place of residence of respondents participating in the survey 


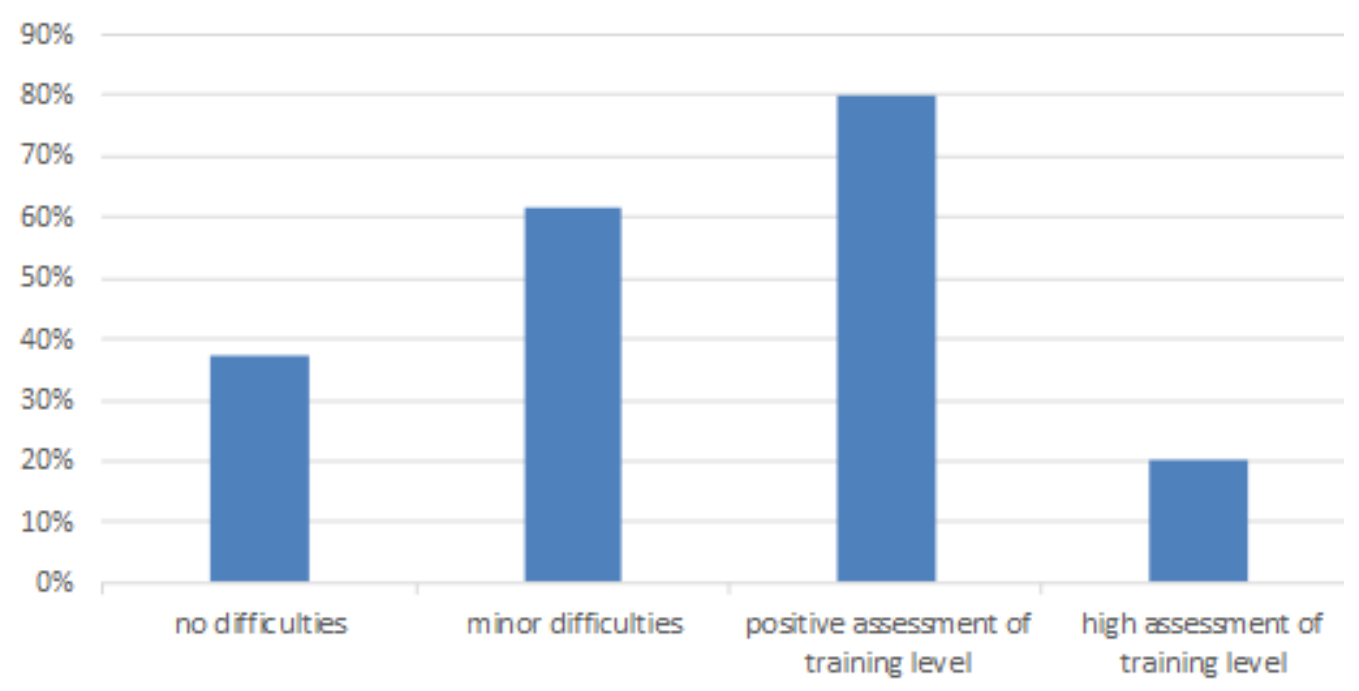

Source: author's survey

Fig. 3. Results of students survey in the framework of the study of satisfaction of distance learning

From the analysis of the questionnaires, we can see that the most satisfied were students living in cities of Kazakhstan and the most difficulties were experienced by those students living in the rural regions. The cause for that could be that in the rural regions there are problems with internet coverage and technical availability. However, to study correlation in more detail further investigations would be necessary after completion of the full Physics course.

\section{Conclusions}

1) Digitalization is important not only because it has been defined in national strategies, but also because it is important for the balanced development of the country and the provision of equal opportunities in education for the population throughout the country, especially in the regions.

2) In this paper, we presented the model of training of the technical competences of students in the Physics discipline, developed basing on the needs of future professional qualification in the conditions of distance learning. The model was presented for the case of the students in the field of electrical engineering at our universities.

3) The survey of the first year distance students of the programme of Electrical Engineering showed quite high satisfaction with the distance learning, except for residents of remote rural areas.

4) Thus, the digitalization of education on the example of online distance learning in physics based on the use of professionally directed learning has shown the possibility of improving the quality of training in the studied discipline, increasing the levels of formation of technical competencies of future bachelors in the field of engineering.

5) The presented case study of the organizing distance learning studies in Physics, giving positive results, is very important for further application and giving very important contribution to the sustainable rural development.

\section{Bibliography}

1. Ageeva, N.V. (2004). Kak razrabotat' model' tekhnicheskikh kompetentsiy. (Development of a Model of Technical Competence). Moscow: HR business, 2004, p.152.

2. Aldous, H. (2000). Education and Business: Partners in Building Human Capital, in Human Capital and Corporate Regulation. Institute of Chartered Accountants, A. Carey, N. Sleigh-Johnson. London: Education Press.

3. Arabadzhi, V.A. (2010). Creative Search in Work with Teachers. DOW Management, no. 3. pp. 26-28. 
4. Armstrong M., Baron A. (2004). Managing Performance. Performance Management in Action. CIPD. London: Capital.

5. Borisova, L. A. (2006). Razvitiye tekhnicheskikh kompetentsiy studentov na osnove informatsionnykh tekhnologiy obucheniya (Development of Technical Competences of Students on the Basis of Information Technologies of Education). Abstract of dissertation for the degree of candidate of pedagogical sciences. Kazan, 2006, p.57.

6. Boyatzis, L., Richard, E. (1982). The Competent Manager: a Model for Effective Performance. John Wiley \& Sons. no. 4. pp. 83-95.

7. Byham, W.C. (2016). Developing Dimension-Competency-Based Human Resource Systems. Development Dimensions International, Kevin W and Bernthal. no. 1. pp. 62-79.

8. Great Russian Encyclopedia (1993-1999). Moscow.

9. Cakir M. (2008). Constructivist Approaches to Learning in Science and Their Implications for Science Pedagogy: A Literature Review. International Journal of Environmental and Science Education, 3(4), 193-206.

10. Gosudarstvennaya programma «Tsifrovoy Kazakhstan» na 2017-2020 goda, razrabotannaya na osnove Ukaza Prezidenta Respubliki Kazakhstan ot 01.02 .2010 goda № 922 «O Strategicheskom plane razvitiya Respubliki Kazakhstan do 2020 goda» (State Programme Digital Kazakhstan 2017- 2020, Elaborated due to the Order of the President of the Republik of Kazkhstan, from 01.02.2010. Nr. 922 "About the Strategic Development of Republic of Kazakhstan till 2020").

11. Mazhitova, L.H., Nauryzbayeva, G.K. (2010). On the Problem of the Formation of Professionally-Oriented Competencies of Undergraduate Students of a Technical College. Materials of the III Republican Scientific Practical Conference. Almaty, 2010, pp. 74-76.

12. Martin, L. (2013). Developing Entrepreneurial Competencies-an Action-Based Approach and Classification in Education. Licentiate Thesis, ISSN: 1654-9732. Report number L2013:070. (c) Martin Lackéus.

13. Tashkeyeva, G., Abykanova, B., Idrissov, S. Intensification of Students' Creative Activity in Educational Environment of Higher Educational Institutions. Life Science Journal 2014, 11(SPEC. ISSUE 11), pp. 133-137.

14. Tashkeyeva, G., Adilzhan, K., Yessenamanova, K., Khamitova, M., Nauryzbayeva, G. Practice-oriented Education in Universities: Opportunities and Challenges. International Multidisciplinary Scientific GeoConference Surveying Geology and Mining Ecology Management, SGEM, 2020, (5.2), pp. 837-844.

15. Zvezdova, A.B. (2012). Innovatsionnyye pedagogicheskiye tekhnologii: Aktivnoye obucheniye (Innovative Pedagogical Technologies: Active Training). - Moscow: Science. p.104. 